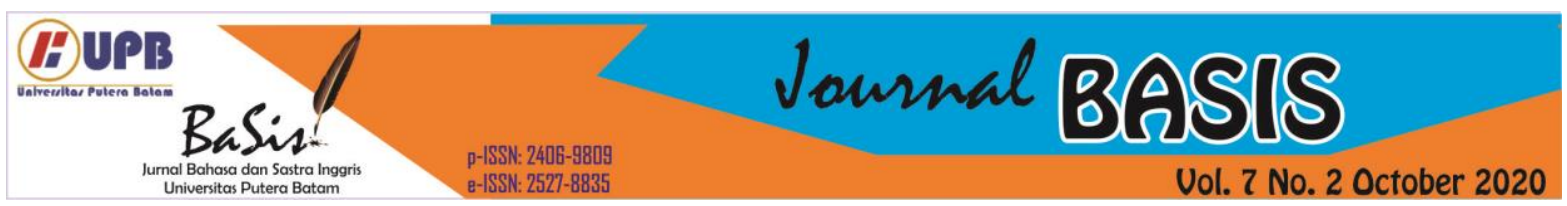

\title{
FIGURES OF SPEECH REFLECTING LOATHING
}

\author{
Ambalegin \\ Universitas Putera Batam, Batam, Indonesia \\ Ambalegin@puterabatam.ac.id \\ Tomi Arianto \\ Universitas Putera Batam, Batam, Indonesia \\ Tomi.arianto@puterabatam.ac.id
}

\begin{abstract}
This descriptive qualitative research identified briefly the figurative expressions on Donald Trump's tweeter post. It used Abrams and Harpham's theory. This research applied observational method and non-participation technique in collecting the data. Then, this research applied semantic identity method and semantic-competence in equalizing to analyze the data. The figure of similarity found mostly in the comments or responses. There were expressions of simile, metaphor, allusion, and personification. The comments or responses mostly compared the one to the other living or non-living things to express how loathe the writers of comments. The figures of speech criticized the one's works and acts. On the other hand, the expressions attacked the face (FTA). Previously, the figures of speech were used in the literary works to show the expression aesthetically. But now, the freedom to express the ideas makes the figures of speech not only to show the 'sweet and smooth' language but also 'rude' language.
\end{abstract}

Keywords: aesthetic expression, figure of speech, loathe

\section{INTRODUCTION}

"When you water the flowers, you need water". It is the written utterance taken from the chats on WhatsApp group. Literally, the basic description is "water is needed when someone waters the flowers". But if the chats are grasped from the beginning, the meaning will be different. Then the chat was started from the one who wanted to speak English. The other one responded by saying "I believe as the time goes by, they will soon be able to chat in English. We haven't started the class yet". And, the response was "When you water the flowers, you need water". This utterance is metaphorical or figurative. This utterance means that the one needs to prepare English skill before entering the class.

In fact, the metaphorical and figurative use occurs in our daily life. Mostly it appears on literary works. It appeared on Shakespeare' sonnet as in phrases 'autumn years" and "takes rose" (Dancygier \& Sweetser, 2014) as a figurative language. They also mentioned that figurative meaning is part of the basic fabric of linguistic structure. And it is not for special literary language but for everyday language.

Metaphor is familiar to one of the ethnics in Indonesia. Malay explores and exploits the words, phrases, and sentences in different medium with aesthetic language structure (Ambalegin \& Arianto, 2020). The 
ability of rhetoric in a Malay oral activity is to avoid the silly talk or heated discussion (Tambak \& Sukenti, 2017). Osman (as cited in Effendy, 2014) said that the Malay utterances show that they communicate in indirect speech act. Indirect speech act is the way to talk politely (Leech, 2016). Communication needs language as the media to produce some utterances that contain meanings (Andy \& Ambalegin, 2019). Thus, meaning and communication cannot be felled apart. The metaphorical and figurative use in expression the ideas is important to smoothen the physical utterances. It is important to hide the anger, the temper by showing this figurative expression to avoid the uncomfortable conversation condition either offline or online.

'Time is money' is one of the expressions to show the importance of not to kill the time. A good choice of figurative language is just to add an aesthetic value in some conversation related to the emotional involvement and artistic effect (Dancygier \& Sweetser, 2014). Figurative language is like one of the flowers in a beautiful flowers garden to enrich the variety of language style.

In digital era, communication appears both online and offline. Social media nowadays is very familiar to express their ideas. People are able to comment freely on behalf their correct opinions. They respond all the written ideas with their own language styles; sweet, bitter, polite, impolite, good, or bad to show appreciation, suggestion, critic, or complain such as "RI economy ready to takeoff (Ayu \& Maili, 2016), "a traveler between life and death" (Agustini, Resen \& Yadnya, 2016). It was found that from the comments, it could appear "hater" because of the disagreement, sarcasm, or criticizing. Figurative use is actually applied on communication to avoid social conflict and disharmony.

Kusumawardhani \& Doyin (2019) discussed the form, function of figurative language and imagery in poetry set Melihat Api Bekerja by M. Aan Mansyur. This study came to the results that there were 76 figurative languages consisting of 27 similes, 17 metaphors, 18 personifications, 3 metonymies, 3 synecdoches, and 8 idioms; second, there were 77 imageries consisting of 41 visual images, 8 audio images, 2 smelling images, 1 tasting image, 19 palpability images, and 6 movement images; third, there were 6 correlations of figurative and imagery language.

Then Wibisono \& Widodo (2019) discussed the article to find out the kinds and the meaning of figurative language used in selected short story on online the Jakarta Post. They found some types of figurative language in the short story; those were personification, simile, symbol, and onomatopoeia. Personification was one of types of figurative language mostly found in the short story posted on online Jakarta Post.

Famous people bring influence to the society. Society attempt to follow their lives. Most of the famous people performed their activities on social media such as tweeter. Donald J. Trump, A USA president, expresses his ideas on tweeter. Many commented his ideas regardless good or bad. This research found out the figurative expression of tweets on Donald J. Trumps' tweeter. One of the tweets showing figurative expression was

"Excellent! If you're not onboard the TRUMP TRAIN, then GET OFF". 


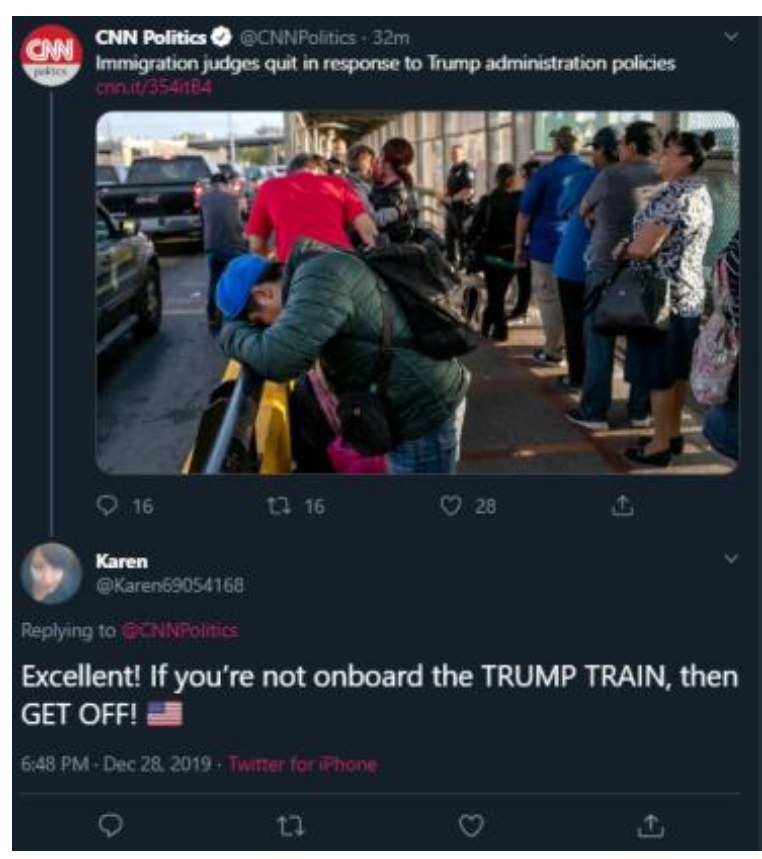

This research applied the theory of figure of speech of figurative language proposed by Dancygier \& Sweetser (2014) and Abrams \& Harpham (2012). Figurative language is the language that employs various figure of speech. Figurative language expresses meaning in utterances with difference from literal interpretation. Figurative language can be used in daily conversation, but mostly it is used on written expression. In fact, figurative expression could be seen on social media. Figurative expression is divided into similarity, contradiction, contiguity, and sound.

\section{LITERATURE REVIEW}

\section{A. Figures of Similarity}

1. Simile

Simile is an expression to compare something to something or between two distinctly different using like or as, for example;

My brother's good as gold (Wibisono \& Widodo, 2019).

2. Metaphor
Metaphor is an expression in term of word or phrase to describe somebody, something, or situation in a way that is different from its normal use without asserting a comparison (without using like or as) in order to show that the two things have the same qualities and to make the description more powerful, for example;

Her teeth are pearl (Hayati, 2016)

3. Illusion

Illusion something that is written referring to a passing reference without explicit identification, to a literary or historical person, place, or even, or to another literary work or passage, for example;

from May-time and cheerful dawn (Agustini et al., 2016).

\section{Personification}

Personification is an expression that says a non-living thing acting like human abilities or human reaction, for example;

About his neck, dead bird is hung (Daniswara, Winaya \& Parthama, 2016).

Sky and sea were jealous to a human's sky (Kusumawardhani \& Doyin, 2019).

\section{B. Figure of Contradiction}

1. Hyperbole

Hyperbole is the expression in term of speaking or writing that makes something bold overstatement or the extravagant exaggeration of fact or possibility, for example;

.... coz you make my heart race (Fitria, 2018).

\section{Litotes}

Litotes is a special form of understatement or the assertion of an affirmative by negating its contrary. Litotes can be said as producing negative statement to emphasize a positive meaning, for example; 
He is not a brightest man in the world (He is stupid) (Abrams \& Harpham, 2012).

\section{Irony}

Irony is an expression used in the opposite of the thought in the one's mind thus conveying the meaning that contradicts the literal meaning, for example;

The love of living death (Daniswara et al., 2016).

\section{Figures of Contiguity \\ 1. Metonymy}

Metonymy is the literal term for one thing is applied to another with which it has become closely associated because of a recurrent relation in common experience, for example;

The white house for the president of the USA (Fitria, 2018).

Good spirit for an angel (Daniswara et al., 2016).

2. Synecdoche

Synecdoche is an expression that is a part of something used for a whole (partwhole relationship), for example;

Ten hands for ten workers (Abrams \& Harpham, 2012)

Hired hands for workmen (Fitria, 2018) Australia lost by two goals (Ayu \& Maili, 2016).

\section{Figure of Sounds}

A figure of speech sound is characterized by repetition of sound conveying a particular effect.

\section{Alliteration}

Alliteration is the repetition of speech sound in a sequence of alliterative meter (Abrams \& Harpham, 2012). The repetition is about the sound at the beginning of the words, for example;

When to the sessions of sweet silent thought (Abrams \& Harpham, 2012).

\section{Onomatopoeia}

Onomatopoeia, sometimes called echoism, is used both in a word or a combination of words, whose sound seems to duplicate the sound it denotes:

"hiss,"“buzz,"“rattle,"“bang." (Abrams

\& Harpham, 2012)

Onomatopoeia could be the sound of animals and birds' cry, the natural sounds of rain and wind, the sound of a clock, vehicle machine, etc., for example;

boschhhh merges the brand name bosch (Sobrino, 2007).

\section{RESEARCH METHOD}

This is a descriptive qualitative research. Qualitative is used to identify the phenomena occurring to daily life (Creswell, 2012). The tweets from tweeter post of Donald Trumps that contained of figurative expression were the data sources. This research applied observational method in which the data were collected by seeing, hearing, reading, and watching carefully for the period of time (Sudaryanto, 2015). Nonparticipation was the technique in collecting the data because the action with no researcher's taking part in an activity or event of participants. Also, this research applied semantic identity method and semantic competence in equalizing (Sudaryanto, 2015) by using Abrams \& Harpham's (2012) theory to analyze the data.

\section{FINDING AND DISCUSSION}

\section{A. Findings}

1. There were 25 expressions showing figure of speech taken from tweets of Trump's accounts.

2. The expressions shown figures of speech simile are;

a. .... whistleblower is like a criminal on trial demanding the name of the person that called 911 to report his crime 
b. Trump is like a cornered animal

c. Trump's emotional feebleness like a fiddle

d. ...... as lame duck

e. Trump is 'Dumb as a Rock and Lazy as Hell

f. ... is more like the end of the world

g. who didn't age like milk

h. Trump is like a clickbait

i. They are just as corrupt as you are

3. The expressions shown figures of speech metaphor are;

a. You're all about rainbows and unicorn farts

b. Trump is a loose cannon

c. Trump is kissin' a-lot-a butt

d. Trump Train

e. Play is "work" for toddlers

f. Donald Trump is a fighter

g. He's a hot mess

h. What is the difference between Donald Trump and a pencil?

i. California has become a cesspool

j. was heaven sent

$\mathrm{k}$. donaldtrump is one sick

1. This guy's such a piece of garbage m. Man you are a scardy cat

4. The expressions shown figures of speech allusion are;

a. Are you really Charles Dickens?

b. ....as the Jussie Smollet

5. The expressions shown figures of speech personification is "Hate never wins".

6. The figurative expressions showed loathing by comparing one to another thing unrelated.

\section{B. Discussion \\ Data 1}

You're all about rainbows and unicorn farts /you live in the land of stupidity and glitter /it's not too late to repent /save yourself OMG what a waste! (@WildaCarmel).

The tweet showed metaphoric expression. 'You're all about rainbows and unicorn farts', it compares one's behavior and rainbows and unicorn farts. Since USA legalizes LGBT, rainbows and unicorn farts symbolizes of LGBT.

\section{Data 2}

Trump is a loose cannon who feels he doesn't need congressional approval for war with Iran or anybody else. It's wrong for any US President (@H...).

The tweet showed metaphoric expression. 'Trump is a loose cannon', it compares Trump's feeling and a loose cannon. Trump proudly said to fight against Iran but he did not need congressional approval that it could not happen in USA.

\section{Data 3}

Trump demanding the name of the whistleblower is like a criminal on trial demanding the name of the person that called 911 to report his crime (@MisterZip).

.... whistleblower is like a criminal on trial demanding the name of the person that called 911 to report his crime, the tweet has the figurative meaning with a figure of speech simile. The twitter compared how similar Donald Trump's situation with another imaginary scene. The tweet showed that Trump reported one's mistakes that actually he reported his mistakes.

\section{Data 4}

I would have expected \#RINO McCain to vote impeachment. He hated our President. I 
just hope he was able to see the pearly gates; thought I have my doubts. Hate never wins (@VickyForT45).

The tweet indicates personification figure of speech "Hate never wins",. "Hate" is a non-living thing and does not have the characteristic of human abilities or reactions, winning or losing.

\section{Data 5}

Meanwhile, at our house \#Trump is kissin' a-lot-a-butt these days...

(@ NienkenWijnants)

Trump is kissin' a-lot-a butt these days is metaphor. Metaphor is the attribution of a human trait or quality to something non-human. In the picture, Trump's face is printed on the toilet paper. In America, toilet paper is used to clean anal area. Thus the metaphoric expression is shown... is kissin' a-lot-a butt.

\section{Data 6}

Excellent! If you're not onboard the TRUMP TRAIN, then GETOFF! (@Karen69054168).

Trump Train in this sentence is metaphor. The word Trump Train is presupposition of the policies that Trump made for the immigrants. Trump's role is the one who controls the policies. He's the machinist in his own train. So, if the immigrants won't follow the rule, they can leave.

\section{Data 7}

Trump is like a cornered animal and when the facts and evidence are not on his side, he lashes out with a barrage of personal attacks on Nancy Pelosi and the people of California. These ad hominem attacks reveal Trump's weak atate of mind and how scared he is about the evidence (@eugenegu).

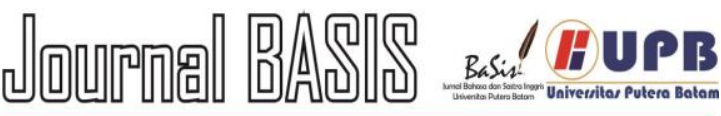

The tweet shows simile expression. "Trump is like a cornered animal and when the facts and evidence are not on his side", it compares Trump's feeling and cornered animal. The expression described the situation of Donald Trump who is currently facing impeachment.

\section{Data 8}

Play is "work" for toddlers (@ungerbn103).

The tweet showed metaphoric expression. 'Play is "work" for toddlers', says about Donald Trump who said he would spend his vacation time to work but in fact he was playing golf. So the tweet mentions that Donald Trump is a toddler by comparing the words "play" and "work".

\section{Data 9}

DonaldTrump is a fighter (@GermanyTRUMP).

This tweet expresses figurative meaning which is classified as metaphor. 'Donald Trump is a fighter', the user replied about Donald Trump made NASDAQ hits 9000 for the first time. The user stated Donald Trump is a fighter (great president) for America because of what he made for the country.

\section{Data 10}

The speaker has played Trump's emotional feebleness like a fiddle (@iTweetyNerd).

The tweet shows the expression of simile. 'The Speaker has played Trump's emotional feebleness like a fiddle', the user similized Trump emotional feebleness with a fiddle. There is the word like to compare.

\section{Data 11}

Nothing is funny about Trump! He's a hot mess! Wake up people! Seriously

(@KATMill75314876).

This statement expresses a figurative meaning of metaphor. "He's a hot mess" expresses Trump is not good to be a president because he is easy to be angry and Trump is compared with a hot mess. 
Vol. 7 No.2 October 2020

e-ISSN : 2406 - 9809 p-ISSN : 2527 - 8835

\section{Data 12}

What the Dickens are you talking about?

Are you really Charles Dickens?

(@blahblahblah936).

The tweet expresses a figurative meaning. Donald Trump is compared to Charles Dickens. Charles Dickens is a famous writer from England. Charles Dickens was the greatest novelist. So, on these statements the writer assumes that Donald Trump talking like Dickens that is good at words. These statements classified as Allusion.

\section{Data 13}

What is the difference between \#DonaldTrump and a pencil? A pencil has a point (@theirkedgod).

......\#Donald Trump and a pencil?

..., the tweet is categorized as Metaphor. There are two unrelated things, Donald Trump \& Pencil, that is being compared. Both are different creatures, but yet they are compared sarcastically.

\section{Data 14}

My greatest fear is that @ realDonaldTrump _LOSES_@Election2020 and has almost 3 months as a lameduck (@Boxster2004).

.... as lame duck", the tweet is categorized as a Simile because it has a comparison on the statement to similar thing using "as" (lame duck).

\section{Data 15}

It should be that Trump is "Dumb as a Rock and Lazy as Hell!!!!”(@uyeda1_n).

The tweet shows the expression of simile, "....... Trump is 'Dumb as a Rock and Lazy as Hell!!!". It is comparison between two different things with the word 'as'. The comparison is between Trump's characteristics and the non-living things.

\section{Data 16}

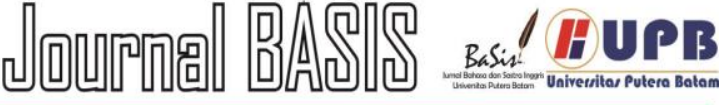

When Donald Trump being a cameo in Home Alone 2 is more like the end of the world cause people getting annoyed because of that (@tennohira).

'...is more like the end of the world' is Simile. It is comparison between 'Donald Trump being a cameo' and 'is more like the end of the world'. It is comparison between two different things with the word 'like'.

\section{Data 17}

This story has about as much credibility as the Jussie Smollet or racist Covington Kids stories (@Varun)

This tweet was commenting or replying on what Donald Trump had tweeted about. The person who tweeted was comparing on what Donald Trump tweeted that was as racist as an incident of an American actor, Jussie Smollet, who was recently involved in a case which he faked racial attack by sending himself a threatening letter and hiring two people to stage an attack on him. His accomplices also allegedly shouted homophobic and racial slurs. The person also compared on Donald Trump's tweet with a case about Covington kids that did a racist bullying towards a man that was playing a tribal drum in front of them. This sentence is identified as Allusion. For the conclusion, Donald Trump's tweet was about as the same as the other two cases involved in racism.

\section{Data 18}

California has become a cesspool (@MMUN61).

This tweet was a reply towards Donald Trump's tweet that talked about California. Apparently, this person said that California has become a place like a cesspool. Cesspool is a strong word meaning corrupt or a wasteland, sort of bad place. This 
sentence is identified as Metaphor, because it is comparing between a country and a place that is unrelated yet. For the conclusion, California is like a bad place that has become a wasteland or full of corruption.

\section{Data 19}

All I'm saying is that I've never seen a trump supporter who didn't age like milk (@BugGirlOfficial)

"......who didn't age like milk", this tweet talks about Trump's supporter. In this tweet she tried to express how worst Trump's supporter is. Furthermore, the purpose of the phrase "age like milk" is to describe something that gets worst as the time goes.

The "age like wine" and "age like milk", from those two phrases wine gets better with age and milk gets worst. Hence, this tweet consists of simile in figurative meaning as she used the word milk to compare it with the Trump's supporter.

\section{Data 20}

There's so much to be thankful for regarding out POTUS Trump! I truly believe this man was heaven sent in order to save and protect the most gracious, benevolent, and in turn, prosperous country ever. God bless him and his family (@DaveSchreiber3)

"... this was heaven sent", in this tweet he/she believed he was a heaven sent because he thought trump was kind-hearted. And also, it is known that heaven was always used to describe a good thing or a good place. Moreover, it is concluded this tweet as a metaphor in figurative meaning cause he/she compared between two things that are unrelated.

\section{Data 21}

This guy's such a piece of garbage. No respect for anyone or any law. This is way Russia hacked our votes to get this \#Moron installed \& why trump* \& Sessions locked away \#RealityWinner to hide Russias votehacking trump*wasn't voted in, he was \#HAckedIn! \#trumpWasHAckedIntoOffice (@LillcyTweets).

"This guy's such a piece of garbage" has a figurative meaning or to be specific this is a metaphor. The tweet shows the meaning by saying something is something else. A piece of garbage is a phrase which refers to someone or something that is useless or worthless. Back to the sentence, this tweet is talking about a guy that is useless.

\section{Data 22}

Trump is like a clickbait decided to take human form (@bengreenman).

The expression contains figurative meaning because it is comparing two different things. The two things being compared are Trump and Clickbait decided to take human form. Clickbait is known to exaggerate something to make a person click on it. The comparison means Trump is exaggerating himself. This form of comparison is called Simile.

\section{Data 23}

Because don't have a clue how much of a con-man you are,or they are just as corrupt as you are! Or both (@MichealBean).

...they are just as corrupt as you are!, the expression contains figurative meaning because it is comparing two different things. The two things being compared are Trump and other people. The other people are described as corrupt by the twitter post. The comparision means Trump is corrupt like the 
other people. This form of comparison is called Simile.

\section{Data 24}

Now he is retweeting a picture of \#SpeakerPelosi's home.... \#donaldtrump is one sick,mf'er (@MilesQBlack).

\#donaldtrump is one sick..., the expression has a figurative meaning, especially in metaphor. It shows something as something else. Word "one sick" is a phrase that refers to a crazy one.

\section{Data 25}

Man, you are a scardy cat (@JimboLeary).

"....... a scardy cat", the expression has a figurative meaning of metaphor. scardy cat" is a noun phrase that refers to someone frightened by almost everything or someone who is shy aways from facing their fears. The tweet talked about Donald Trump that frightened or shy facing his fear.

\section{CONCLUSION AND SUGGESTION}

Figures of speech or figurative languages are not only found in literary works, but also nowadays they are expressed in writings digitally. People are able to express freely their opinions on social media that can be read freely too. Social media is like "a bowl of comments". The expressions are showed not in classical style but modern style. The opinions showed on media social tweeter post are expressed stylistically. The tweets contained of simile, metaphor, allusion, and personification. Mostly the expression mentioned the comparison, and the comparison represented the loath-some comments or responses. The negative-content comments or responses attacked the one's face on tweeter post.
Figures of speech or figurative languages are mostly used in literary works to give an aesthetic effect to the readers. Nowadays, the use of figurative expression hopefully is functioned to avoid the rude opinion that is able to stop the hate speech or loath-some comments or responses. 'Haters' is a common word now. But why it is not 'lovers'. Recently, many comments on social media showed hate speech or loathsome comments or responses that make disharmony because of FTA. People do not pay attention the way of language used, whom they speak to, and what beautiful words they choose (Suryani, 2019). The use of correct figurative languages on comments or responses either orally or written is able to create more 'lovers' than 'haters'.

\section{REFERENCES}

Abrams, M. H., \& Harpham, G. G. (2012). A glossary of literary terms (10th ed.). Wadsworth, Cengage learning.

Agustini, E., Resen, W., \& Yadnya, P. (2016). Figurative languange in William Wordsworth's poem "She Was a Phantom of Delight." Jurnal Humanis, Fakultas Ilmu Budaya Unud, 16(3), 30-36. https://ojs.unud.ac.id/index.php/sastra/a rticle/view/28939/17954

Ambalegin, \& Arianto, T. (2020). Segmental phonemic system of Riau Malay subdialect Kepulauan as local knowledge in Batam. EduLite: Journal of English Education, 5(5), 159-175. https://doi.org/DOI: http://dx.doi.org/10.30659/e.5.1.159175 
Andy, \& Ambalegin. (2019). Maxims violation on "Night at The Museum" movie. Journal Basis, 6(2), 215-224,. https://doi.org/DOI:

https://doi.org/10.33884/basisupb.v6i2. 1421

Ayu, D. M. I., \& Maili, S. N. (2016). The analysis figurative meaning of Jakarta Post a paper. DEIKSIS, 8(8), 102-110. https://doi.org/https://journal.lppmunin dra.ac.id/index.php/Deiksis/article/view 1672

Creswell, J. W. (2012). Educational research; planning, conducting, and evaluating quantitative qualitative research (4th ed.). Pearson Education Inc.

Dancygier, B., \& Sweetser, E. (2014). Figurative language (1st ed.). Cambridge University Press.

Daniswara, R., Winaya, I. M., \& Parthama, I. G. N. (2016). Meanings of figurative language with reference to Four Iron Maiden songs. Jurnal Humanis, Fakultas Ilmu Budaya Unud, 17(2), 241-247.

https://ojs.unud.ac.id/index.php/sastra/a rticle/view/34494

Effendy, C. (2014). Peranan sastra dan bahasa Melayu dalam membangun karakter bangsa. Jentera, 3(2), 126$134 . \quad \mathrm{https}$ ://doi.org/DOI : 10.26499/jentera.v3i2.443

Fitria, T. N. (2018). Figurative language used in One Direction's album entitled Up All Night. ELITE Journal, 5(1), 6979.

https://doi.org/https://doi.org/10.24252/



elite.v5i1a7

Hayati. (2016). Figurative language on Maya Angelou selected poetries. Script Journal: Journal of Linguistics and English Teaching, 1(2), 131-143. https://doi.org/https://doi.org/10.24903/ sj.v1i2.30

Kusumawardhani, O. A., \& Doyin, M. (2019). Figurative and imagery language in poetry set Melihat Api Bekerja by M. Aan Mansyur: stylistic review. Seloka: Jurnal Pendidikan Bahasa Dan Sastra Indonesia, 8(3), 63-69. https://doi.org/DOI 10.15294/seloka.v8i3.35382

Leech, G. N. (2016). Principles of pragmatics. Routledge.

Sobrino, P. P. (2007). Multimodal metaphor and metonymy in advertising (vol 2). John Benjamins Publishing Company.

Sudaryanto. (2015). Metode dan aneka teknik analisis bahasa. Duta Wacana University Press.

Suryani, M. S. (2019). Impolite responses to Donald Trump's post on instagram. Jurnal IdeBahasa, 1(1), 77-84. https://doi.org/DOI:

https://doi.org/10.37296/ide\%20bahasa. v1i1.7

Tambak, S., \& Sukenti, D. (2017). Implementasi budaya Melayu dalam kurikulum pendidikan Madrasah ibtidaiyah di Riau. Miqot, XLI(2), 362383.

Wibisono, R. T., \& Widodo, P. (2019). An analysis of figurative language in 
Vol. 7 No.2 October 2020

e-ISSN : 2406 - 9809 p-ISSN : 2527 - 8835

http://ejournal.upbatam.ac.id/index.php/basis

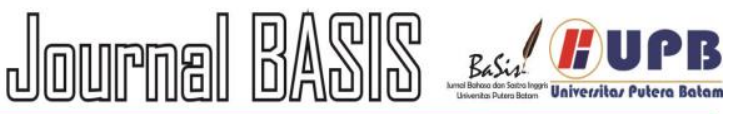

online short story posted on The Jakarta

Post. Prasasti Journal of Linguistics, 4(2), 156-165. https://doi.org/DOI: https://doi.org/10.20961/prasasti.v4i2.3 3876 
Vol. 7 No.2 October 2020

e-ISSN : 2406 - 9809 p-ISSN : 2527 - 8835

http://ejournal.upbatam.ac.id/index.php/basis 